\title{
Studies on the sensitivity of some species and cultivars of lawn grasses on salinity with sodium chloride during the seed germination and first year of growth
}

\author{
Edward Borowski \\ Department of Plant Physiology, University of Life Sciences in Lublin \\ Akademicka 15, 20-934 Lublin, Poland \\ e-mail: katarzyna.kurek@up.lublin.pl
}

Key words: grasses, $\mathrm{NaCl}$, speed germination, roots, coleoptile, dry mass, sodium, chlorine, proline

\begin{abstract}
In the years 2005 - 2006 studies were conducted in a growth chamber and a vegetation hall which compared tolerance to $\mathrm{NaCl}$ salinity of seeds and plants of some lawn grasses. The effect of sodium chloride salinity on the germination of 4 species of grasses i.e. Lolium perenne cv. 'Info', Festuca rubra cv. 'Audio', Agrostis capillaris cv. 'Niwa', Poa pratensis cv. 'Alicja' and 4 cultivars of Lolium prenne - 'Nira', 'Stadion', 'Ronija', 'Darius' was studied. The grass seeds germinated in Petri dishes, in darkness, at the temperature of $24^{\circ} \mathrm{C}$. Besides the control, 3 levels of salinity were used in the studies: 100, 200 and $300 \mathrm{mM} \mathrm{NaCl}$. The obtained results demonstrated that the growing level of salinity in the environment significantly decreased the germinating speed, the number of the produced roots, the length of the longest root, and the length of the coleoptile in the
\end{abstract}


seedlings of all studied grass species. Lolium perenne seeds tolerated salinity the best, and next - in a diminishing sequence - those were the seeds of Festuca rubra, Agrostis capillaris and Poa pratensis. However, the obtained data showed that tolerance to salinity of the analyzed cultivars of Lolium prenne decreased in the following sequence 'Ronija' > 'Stadion' > 'Nira' > 'Darius'.

In a vegetation hall tolerance to $\mathrm{NaCl}$ salinity of these 4 cultivars of Lolium perenne in the first year growth was compared. The plants grew in pots of $2 \mathrm{dm}^{3}$ filled with a mixture of universal earth and river sand (3:1 / v:v) with the soil moisture of $70 \%$ and 3 levels of salinity: 0,50 , and $100 \mathrm{mM} \mathrm{NaCl}$. The obtained results demonstrated that in all studied cultivars the increase of the salinity level caused a significant decrease of the yield of the leaf dry weight from the successive grass crops, and an increase of the content of sodium, chloride and free proline in them. The greatest tolerance to $\mathrm{NaCl}$ salinity in the group of the studied cultivars was shown by 'Ronija', medium tolerance - by 'Darius' and 'Stadion', and the lowest one - by 'Nira'. This resulted from the degree of accumulation of $\mathrm{Na}^{+}$and $\mathrm{Cl}^{-}$ions and proline in those conditions. The cultivars with higher tolerance accumulated fewer osmotically active compounds in the leaves.

\section{INTRODUCTION}

Salinity of the soil environment is connected with an excessive quality of soluble ions in the soil solution, especially those of $\mathrm{Na}^{+}, \mathrm{Cl}^{-}, \mathrm{SO}_{4}{ }^{2-}, \mathrm{HCO}_{3}{ }^{-}$, and rarely $\mathrm{K}^{+}$, $\mathrm{Ca}^{2+}, \mathrm{Mg}^{2+}, \mathrm{NO}_{3}{ }^{-}$. This leads to the appearance of the phenomenon of physiological drought. Hence, the seeds at germination are most susceptible to salinity stress (Horst and Dunning 1989). Studies in this field on the seeds of different grass species were conducted by Ashraf et al. (1986), Myers and Couper (1989), Kim et al. (1991), Mogsood and Verplancke (1994), Yuying et al. (1999), Xiaofang et al. (2000), Hujun et al. (2001). In Poland, Pawluśkiewicz (2000) dealt with seed germination of 8 species of lawn grasses in the conditions of salinity. However, the results of the studies conducted on grasses so far are frequently ambiguous. For example, Hujun et al. (2001) consider Lolium perenne as a species that is highly tolerant towards salinity, whereas Festuca rubra as fairly or little tolerant, whereas Pawluśkiewicz (2000) found no differences in the germination of Lolium perenne and Festuca rubra with the salinity of $8 \mathrm{mS} \mathrm{cm}^{-1}$. This indicates considerable differentiation of grass seeds within the species, and even cultivars in tolerating salinity, which is also emphasized by Ashraf et al. (1986) and Hanslin and Eggen (2005).

Also at a later growth stage plants are susceptible to salinity, which inhibits growth rate (Stiborova et al. 1987, Bilski 1988, Brzostowicz nad Musiał 1999, Khan et al. 2000, Borowski 2003, Cramer 2003, Yongqin et al. 2003), and, at the 
same time, with increases absorption of excessive ions, particularly hydrophylous ions $\mathrm{Na}^{+}$and $\mathrm{Cl}^{-}$. Such a phenomenon was observed in numerous plant species by Binzel et al. (1987), Bilski (1988), Khan et al. (1995, 2000, 2000), Abdel-Kader and Saleh (2002), Gibbeard et al. (2002), Pervaiz et al. (2002), Mansour et al. (2005). Osmotic adjustment of plants to stress conditions refers not only to increased ion accumulation but easily soluble organic substances as well, particularly sugars, amino acids, betaine, and glycinebetaine. Increased accumulation of proline in Lolium perenne in salinity conditions was observed by Yuimin et al. (2001), and in other plant species by Binzel et al. (1987), Roy et al. (1993), Mile et al. (2002), and Mansour et al. (2005).

In Polish agriculture the state of salinity of cultivated plants with sodium chloride does not pose a problem. On the other hand, it can concern the seeds of certain species of lawn grasses that are used in mixtures to establish green belts along traffic arteries outside cities and on street lawns of towns. This is connected with the fact that in our country we still use a mixture of sand and salt to fight the after-snow slippery state of roads in winter time.

Stawicka et al. (2006), for example, observed that on many examined Warsaw streets lawn with salinity oscillated from 0.8 to $1.2 \mathrm{dS} \mathrm{m}^{-1}$ and participation of grasses in total plant cover was only $36.2 \%$. The most abounding grass species on street lawns were: Fastuca rubra and Lolium perenne (Wysocki 1994). For this reason the purpose of the present studies was to establish the tolerance of the seeds of commonly used law grass species to $\mathrm{NaCl}$ salinity at germination (Lolium perenne, Festuca rubra, Agrostis capillaris, Poa pratensis). The studies also established whether there are differences between some widely used Polish and foreign cultivars in relation to the species that proved to be most tolerant to salinity (Lolium perenne) at seed germination and in the first year of growth.

\section{MATERIAL AND METHODS}

The results discussed in the present paper were obtained in two separate growth chamber experiments carried out in 2005 and two experiments in a vegetation hall carried out in 2005 and 2006. In the first experiment the seeds of 4 lawn grass species germinated on Petri dishes $\varnothing 18 \mathrm{~cm}$ laid with 2 layers of filter paper. The seeds of the following grass species: Lolium perenne cv. 'Info', Festuca rubra cv. 'Adio', Agrostis capillaris cv. 'Niwa', Poa pratensis cv. 'Alicja' were used in the experiment. The seeds from the 2004 harvest were purchased in the Małopolska Plant Breeding. The experiment conducted in a growth chamber and the seeds germinated in darkness at the temperature of $24^{\circ} \mathrm{C}$. One hundred seeds germinated on one dish in 5 repetitions. The experiment made use of the control which consisted of the dishes with filter paper soaked with distilled water, and 3 levels of 
salinity, i.e. 100, 200 and $300 \mathrm{mM} \mathrm{NaCl}$. Every day from the beginning of germination, the number of germinated seeds was determined, considering the seeds with a visible sprout as such. A part of the experiment concerning the germination of seeds Lollium perenne and Festuca rubra was finished when the percentage of the germinating seeds in the control $(0 \mathrm{mM} \mathrm{NaCl})$ exceeded 95, i.e. 7 and 8 days after closing the experiment, respectively. Agrostis capillaris and Poa pratensis germinated much more slowly so the experiment with the former was closed after 14 days, while with the other after 24 days. Then, the index of germinating speed was calculated on the basis of the number of germinated seeds (Maguire 1962), while the mean number of the germinal roots on 1 seedling, the length of the longest root and the length of the coleoptile were determined on the basis of 20 randomly selected seedlings from each dish.

The second experiment was carried out in analogous conditions and in the same manner as the first experiment. It determined tolerance of the seeds of 2 cultivars of Lolium perenne from the Polish breeding - 'Nira' and 'Stadion', a Dutch one 'Darius', and a Swedish one 'Ronija' to $\mathrm{NaCl}$ salinity. The seeds of the studied cultivars of Lolium perenne in the control showed a similar germinating speed so the experiment was closed on the $7^{\text {th }}$ day after seed sowing. Additionally, the experiment calculated the mean value of the index of tolerance (It) of the seeds to salinity on the basis of the percentage reduction of the analyzed values of the seedlings in the conditions of the applied levels in relation to the control.

The experiments in a vegetation hall were conducted in the period between April and October of 2005 and 2006. The seeds of two Polish cultivars of Lolium perenne ('Nira' and 'Stadion'), one Dutch cultivar 'Darius', and a Swedish one of 'Ronija' were sown in the quantity of 30 seeds ( 3 seeds in 10 points) into pots of $2 \mathrm{dm}^{3}$ filled with a mixture of universal earth and river sand in the volume proportion of $3: 1$. Each of the four cultivars was found in 15 pots. After emergencies, unnecessary seedlings were removed from the pots, leaving 10 plants in each for further vegetation; the plants were fed with $1 / 2$ concentration of Hoagland's medium. The second dose of this medium was provided in the same quantity a week later. At the same time, 3 experimental series were made within each cultivar and they differed with the level of $\mathrm{NaCl}$ salinity of the soil, i.e. 1) control $-0.0,2) 50 \mathrm{mM} \mathrm{dm}^{-3}$, 3) $100 \mathrm{mM} \mathrm{dm}^{-3}$. Chloride was provided 8 times with 3-day-long intervals depending on the degree of soil salinity at the dose of 12.5 and $25 \mathrm{mM}$, respectively, for one pot in the form of a water solution. The last dose of $\mathrm{NaCl}$ in 2005 and 2006 was provided on the $6^{\text {th }}$ and $9^{\text {th }}$ days of June, respectively, and the first grass harvest was performed with 30-days' intervals. Throughout their growth, the plants were watered with distilled water up to $70 \%$ of the water capacity of the soil.

The paper presents the yields of the dry weight of the leaves of the examined cultivars of Lolium perenne from the first, second and third crops, the percentage 
content of sodium and chloride in the dry weight of the leaves and the content of proline aminoacid in the fresh weight of the leaves from the first and second crops. Because in both years the studies found out a similar reaction of the examined cultivars to the applied levels of salinity, the data presented in the tables are the mean values from the years 2005 and 2006. The content of proline was established using the method presented in the work by Bates et al. (1973), sodium was marked with the method of atomic absorption on ASA apparatus, and chloride was determined using the opacity method using $\mathrm{AgNO}_{3}$ on a spectrocolorimeter. The results were statistically verified using analysis of variance, the significant differences were evaluated using the Tukey test at $p=0.05$.

\section{RESULTS AND DISCUSSION}

The results demonstrated that all four grass species germinated the fastest in the control conditions, with the seeds of Lolium perenne germinating at the mean speed of 32.6 items $\times$ day $^{-1}$, and Poa pratensis germinating at only 8.9 items $\times$ day $^{-1}$. With the salinity of $100 \mathrm{mM} \mathrm{NaCl}$, the germinating speed of Lolium perenne seeds decreased in relation to the control by 22.1, while that of Festuca rubra and Agrostis capillaries seeds dropped by 42.7 and $43.1 \%$ respectively, and that of Poa pratensis as much as by $68.5 \%$. In the salinity conditions at the level of $200 \mathrm{mM}$, the seeds of Lolium perenne, Festuca rubra and Agrostis capillaris decreased germinating by $60.7,87.9$ and $91.3 \%$ respectively. On the other hand, no germination of Poa pratensis was observed. The highest applied salinity inhibited seed germination in all the studied grass species, except Lolium perenne (2.6 items $\times$ day $\left.^{-1}\right)$. Increased salinity of the environment delayed the beginning time of germination of the examined grass species and extended its period, which is also confirmed in the studies on Lolium perenne by Horst and Dunning (1989) and on other grass species by Xiaofang et al. (2000) and Yongqin et al. (2003).

Salinity also significantly reduced the number of germinal roots formed on the grass seedlings (Table 2). The most roots at germination were formed by the seeds in the control conditions. The salinity of the environment at the level of $100 \mathrm{mM}$ $\mathrm{NaCl}$ caused a decrease of the number of roots in Lolium perenne, Agrostis capillaris and Poa pratensis respectively by $14.8,29.0$, and $52.8 \%$. It is interesting that Festuca rubra which had the fewest roots in the control practically did not react to the applied salinity level as far as this feature is concerned. Salinity twice as high as the discussed level caused further decrease of the number of the formed roots. Poa pratensis seeds did not form any roots, while in Lolium perenne this drop in relation to the control reached $33.6 \%$, in Festuca rubra $-67.3 \%$, and in Agrostis capillaris as much as $84.1 \%$. In the conditions of the highest level of applied salinity only the seeds of Lolium perenne produced scarce germinal roots. 

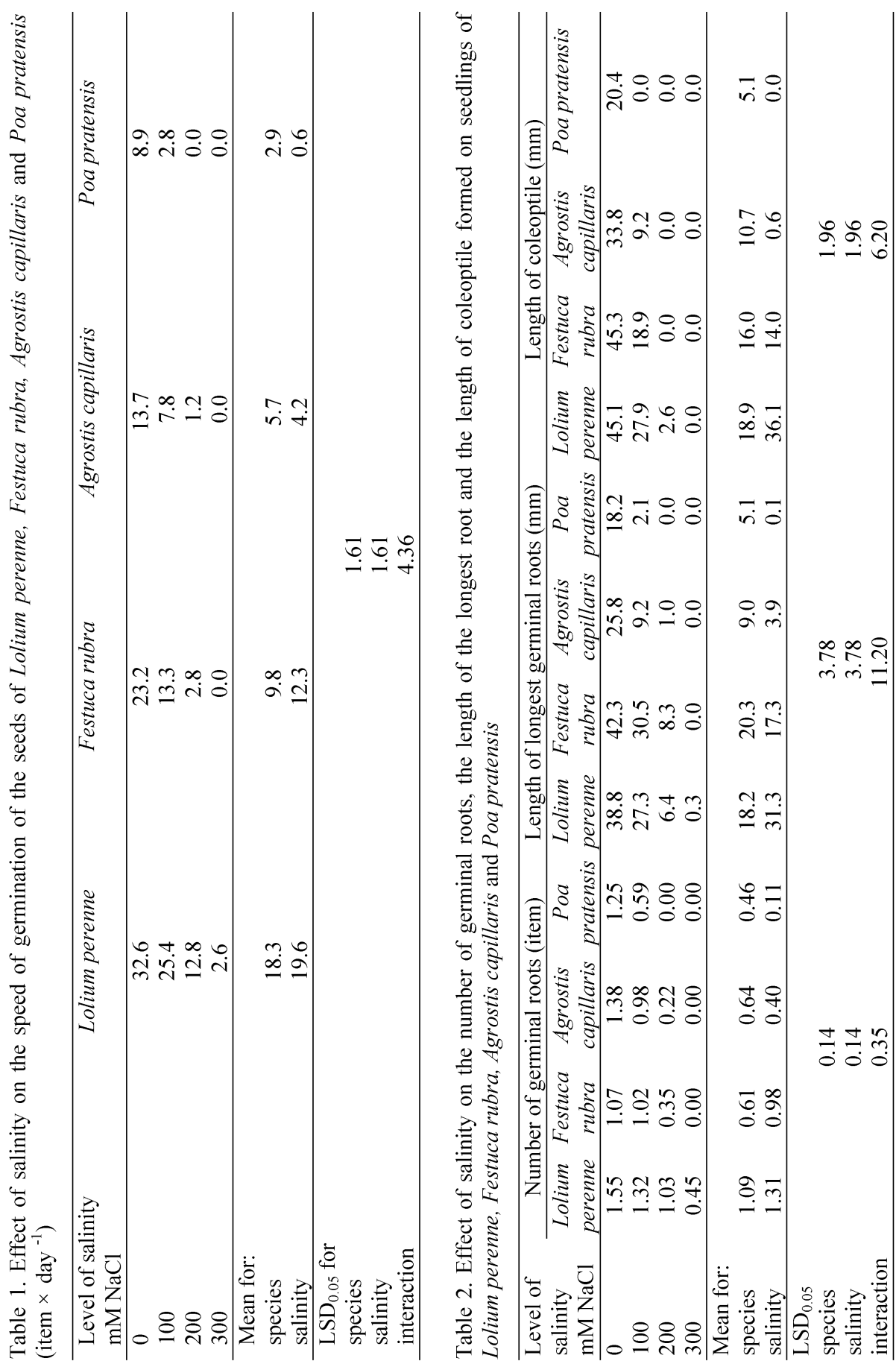
Hence, the most roots - independently of the level of salinity - were produced by Lolium perenne ( 1.09 items $\times$ seedling $^{-1}$ ), while on the average half as few were produced by the seedlings of the other examined grass species $(0.57$ items $\times$ seedling ${ }^{-1}$ ) (Table 2).

The salinity of the environment inhibited the elongation growth of the roots to a much greater degree than their initiation (Table 2). In the control, the longest roots were observed in Festuca rubra, slightly shorter in Lolium perenne, and the shortest in Poa pratensis. Already the salinity at the level of $100 \mathrm{mM}$ rapidly reduced the length of the longest root, and the reaction of the studied grass species in relation to this feature was a little different from their number. The root length was reduced in the smallest degree in Festuca rubra (27.9\%), in a slightly bigger in Lolium perenne $(29.6 \%)$, and in the highest degree - in Poa pratensis $(88.5 \%)$. Increased salinity up to $200 \mathrm{mM}$ caused further dramatic drop of the root growth, reaching more than $80 \%$ as compared to the control in Lolium perenne and Festuca rubra, and more than $96 \%$ in Agrostis capillaris. With the highest salinity, only Lolium perenne seedlings produced the roots with the mean length of $0.3 \mathrm{~mm}$. Horst and Dunning (1989) in the studies on Lolium perenne, and Ashraf et al. (1986) in the studies on 7 different grass species found out clear inhibition of the growth of germinal roots under the effect of increasing concentration of $\mathrm{NaCl}$ in the environment. On the other hand, in the studies by Ashraf et al. (1986), the seedlings of Lolium perenne in the control conditions had longer roots than Festuca rubra roots, but the reduction of their growth under the effect of salinity of 150 and $250 \mathrm{M} \times \mathrm{m}^{-3} \mathrm{NaCl}$ was also higher than in Festuca rubra.

As follows from the studies, salinity inhibits the elongation growth of grass coleoptile the most although in the control conditions those organs grew faster than the roots (Table 2). Seemann and Critchley (1985) in their studies on the effect of salinity on the growth of Phaseolus vulgaris found out greater inhibition of the growth of the aboveground parts as compared to the roots. With the salinity of 100 $\mathrm{mM} \mathrm{NaCl}$, the length of coleoptile in Lolium perenne already decreased by $38.1 \%$, in Festuca rubra by $58.3 \%$, and in Agrostis capillaris as much as by $72.8 \%$. With the salinity twice as high, coleoptile with the mean length of $2.6 \mathrm{~mm}$ were formed only by Lolium perenne seedlings. In the studies on Lolium perenne, Horst and Dunning (1989) also found out strong inhibition of the leaf growth under the effect of increasing salt concentration in the environment.

The inhibiting effect of $\mathrm{NaCl}$ on seed germination and the seedling growth may result from the decrease of the chemical potential of water around the seeds and the consequent problems regarding its intake by the seeds as well as from the excess of $\mathrm{Na}^{+}$and $\mathrm{Cl}^{-}$ions in the environment. The studies by Myers ad Couper (1989) conducted on the seeds of Lolium perenne and Puccinellia ciliate with the use of isoosmotic solutions of different salts as well as PEG and mannitol point mainly to the osmotic effect. The studies showed clear differentiation in tolerance to salinity of 4 examined grass species; Lolium perenne proved to be most resistant, and the following ones were Festuca rubra, Agrostis capillaris and Poa pratensis. 
It is hard to compare the obtained results with the results of studies by other authors as they compare the studied species with others that are not considered in the present paper. However, the data from literature confirm the fact that within the group of lawn grasses Lolium perenne tolerates salinity relatively well (Ashraf et al. 1986, Wysocki 1994, Pawluśkiewicz 2000, Xiaofang et al. 2000, Hujun 2001, Yongqin et al. 2003, Stawicka et al. 2006).

Comparative studies of tolerance to salinity of two Polish and two foreign cultivars of Lolium perenne point out that there also occur cultivar differences within this species (Table 3). The seeds 'Stadion' and 'Ronija' germinated in the control conditions at the speed of 38.4 items $\times$ day $^{-1}$, while 'Nira' and 'Darius' germinated at the speed of 35.6 and 34.0 items $\times$ day $^{-1}$, respectively. In the salinity conditions, the germination speed rapidly decreased, but independently of the quantity of $\mathrm{NaCl}$ in the solution the seeds of 'Stadion' and 'Ronija' germinated faster than the seeds of 'Nira' and particularly those of 'Darius'. Differentiation in tolerating salinity was demonstrated in the seedling growth even more clearly than in the case of germination speed (Table 4). Seedlings of 'Ronija' showed the longest roots with all salinity levels, with the mean root length of $29.5 \mathrm{~mm}$, the roots of 'Stadion' $(26.9 \mathrm{~mm})$ and 'Nira' $(23.9 \mathrm{~mm})$ were significantly shorter, and the shortest were the roots of 'Darius' $(14.8 \mathrm{~mm})$. 'Ronija' also produced the seedlings with the longest coleoptile during the germination, coleoptile of 'Nira' were slightly shorter, those of 'Stadion' were significantly shorter, and the shortest were those of 'Darius'.

The smallest differences between the compared cultivars of Lolium perenne concerned the number of produced germinal roots. 'Darius' produced a significantly smaller number of germinal roots as compared to the other cultivars $\left(0.90\right.$ items $\times$ seedling $\left.^{-1}\right)$, whereas no differences were observed in the value of the discussed feature between the other cultivars (Table 4). The index of tolerance to salinity calculated on the basis of the analyzed features of Lolium perenne seedlings points out that the highest tolerance to all the applied salinity levels in the period of germination was shown by the seeds of 'Ronija', slightly lower by 'Stadion', lower by 'Nira' and the lowest by 'Darius'. The obtained results are confirmed in the studies by foreign authors conducted on Lolium perenne cultivars used in their countries (Yongqin et al. 2003). In Poland salinity tolerance of Lolium perenne cv. 'Nigra' and 'Nira' in the period of seed germination was compared by Pawluskiewicz (2000), who also confirmed a lower tolerance of 'Nira' as compared to 'Nigra'.

Salinity also significantly lowered the growth rate of the examined Lolium perenne cultivars in the first year of growth (Table 6). The mean yield of dry weight obtained from three successive crops of grass growing with $50 \mathrm{mM}$ salinity was by $19.3 \%$, and with $100 \mathrm{mM}$ salinity as much as by $49.6 \%$ lower than the control. 

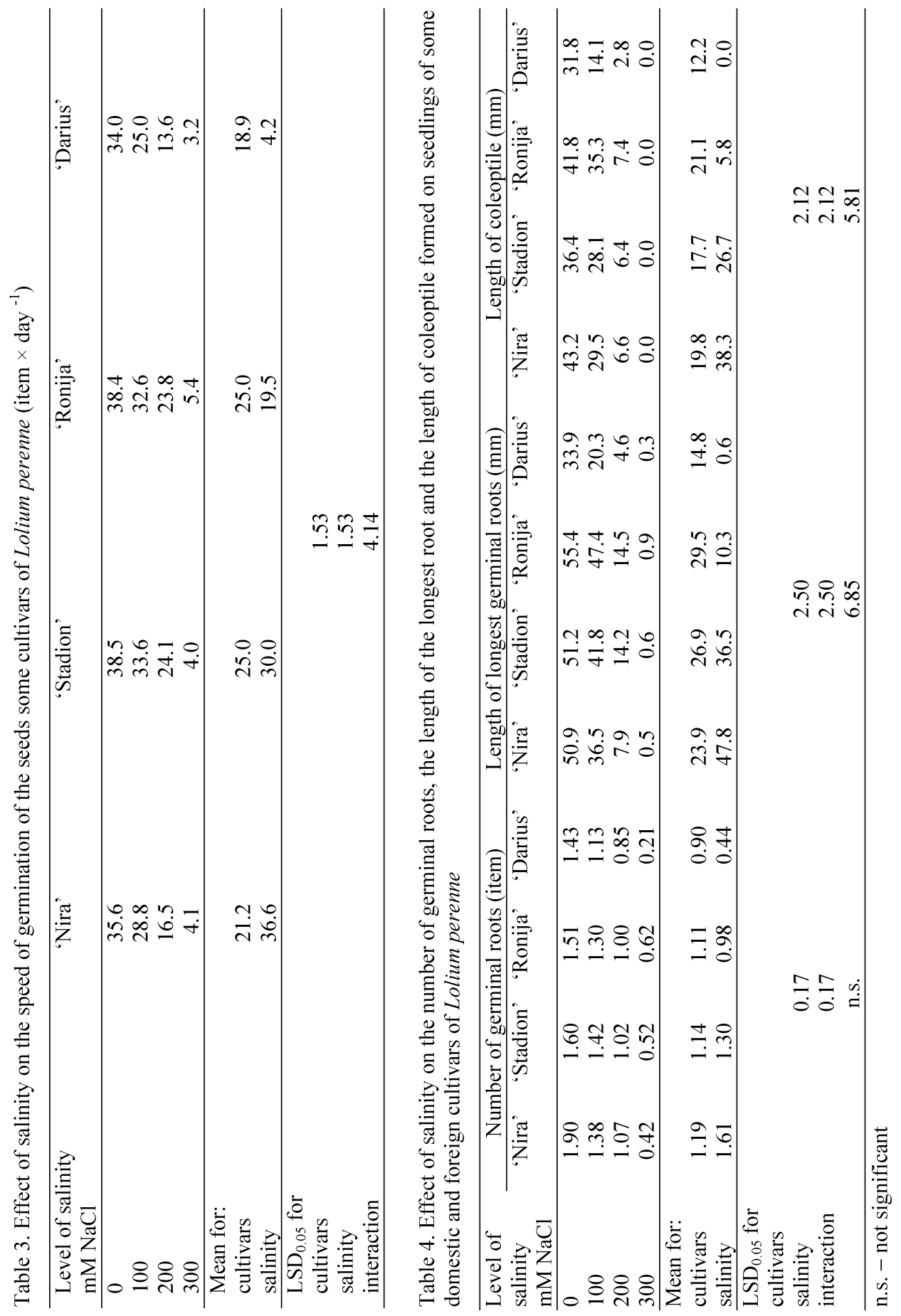


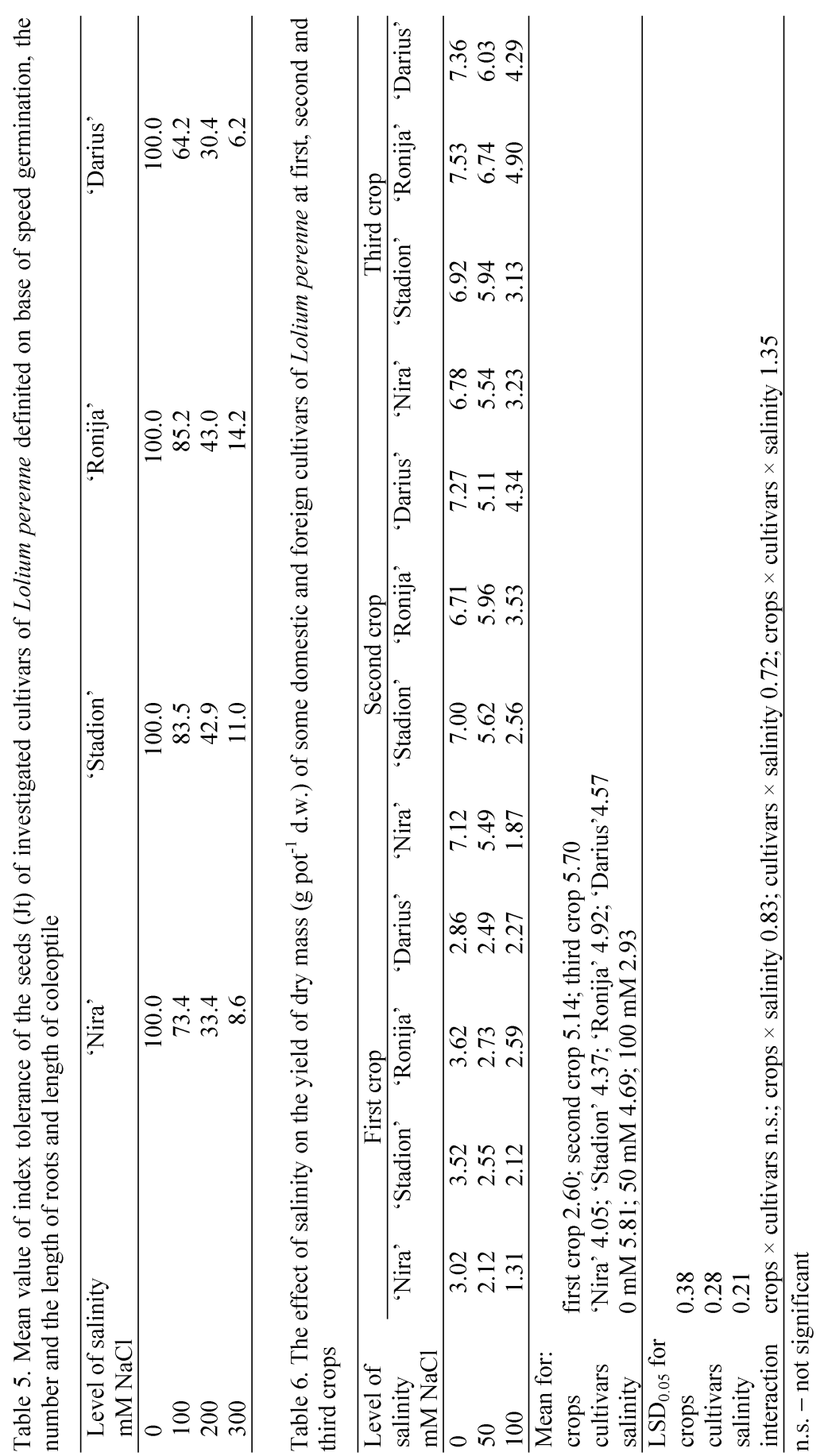


Inhibition of Lolium perenne growth in the salinity conditions was also observed by Yongqin et al. (2003), and for other species of cultivated plants - by Bilski (1988), Brzóstowicz and Musiał (1999), Hussain et al. (2002), Borowski (2003), Cramer (2003), Khan et al. (2000). The reaction of the examined cultivars of this grass species varied. The highest mean dry weight yields of the leaves were given in successive crops by 'Ronija', significantly lower yields - by 'Darius' and 'Stadion' and the lowest - by 'Nira' (Table 6). Differentiated reactions of Lolium perenne cultivars to salinity during their growth was also found out by Yongqin et al. (2003).

Growth inhibition of the examined lawn grass species must have resulted from difficulties in absorbing water by plants, which is testified by a decreased content of $\mathrm{H}_{2} \mathrm{O}$ in the fresh weight of leaves (unpublished data), and at the same time by increased uptake of $\mathrm{Na}^{+}$and $\mathrm{Cl}^{-}$ions with the aim of osmotic adjustment. The obtained results indicate that the mean percentage content of sodium in the dry weight of Lolium perenne leaves grown at the salinity of $50 \mathrm{mM}$ was almost twice, and with the salinity of $100 \mathrm{mM} 2.7$ times as high as in the control (Table 7). Plants accumulated chloride ions even in a greater degree, which is shown by the results contained in Table 8. The mean content of $\mathrm{Cl}^{-}$ions with no salinity was low $(0.59 \%)$ and close to the content of $\mathrm{Na}^{+}$ions; with the salinity of $50 \mathrm{mM}$ their concentration in leaf tissues increased 4.8 times $(2.83 \%)$, on average, whereas with the salinity of $100 \mathrm{mM}-5.8$ times $(3.42 \%)$. Therefore, it seems that in the conditions of $\mathrm{NaCl}$ salinity a high concentration of $\mathrm{Cl}^{-}$ions in tissues exerts a specially harmful influence on plants, with their mean concentration in Lolium perenne leaves - as shown by the studies - nearly 2.5 times higher than in $\mathrm{Na}^{+}$ions. In glycophytes these ions are accumulated not only in vacuola but in cytoplasm as well, where, in the case of leaves, they inhibit the activity of Calvin's cycle enzymes, and particularly rubisco enzyme (Stiborova et al. 1987). Then, on the one hand, $\mathrm{Cl}^{-}$ions taken in excess osmotically adjusted Lolium perenne organs to salinity conditions, but on the other hand, probably due to the inhibition of the process of photosynthesis, they decreased biomass accumulation in the leaves. High accumulation of $\mathrm{Na}^{+}$and $\mathrm{Cl}^{-}$ions in the tissues of cultivated plants in the conditions of $\mathrm{NaCl}$ salinity was also observed by other authors (Binzel et al. 1987; Bilski 1988; Khan et al. 1995, 2000, 2000; Abdel-Kadar and Saleh 2002; Pervaiz et al. 2002; Gibbeard et al. 2002; Hussain et al. 2002, 2003; Borowski 2003, Mansour et al. 2005).

The results included in Tables 7 and 8 both indicate that the studied cultivars of Lolium perenne significantly differed in respect of the mean percentage content of $\mathrm{Na}^{+}$and $\mathrm{Cl}^{-}$ions in the leaves. 'Ronija' contained the smallest number of both ions in the leaves, 'Stadion' and 'Nira' accumulated significantly more of this kind of sodium ions, and all the other cultivars cumulated chloride ions. 'Nira' showed the greatest tendency to accumulate sodium and chloride in the leaves. On this basis it 
can be stated that the highest resistance of 'Ronija' to salinity, reflected in the highest yields of the leaf dry weight in successive crops, results from limited accumulation of sodium and chloride ions in those conditions. Contrary to that, the Polish cv. 'Nira', which showed the highest content of $\mathrm{Na}^{+}$and $\mathrm{Cl}^{-}$in the leaves, gave the lowest yield of the leaf dry weight. A similar relationship within a few species of grasses was observed by Asraf et al. (1990), and within a few cultivars of soybean - by Borowski (2003).

Lolium perenne plants - as is shown by the obtained results - are able to accumulate big quantities of sodium and chloride ions in tissues. In successive grass crops, it was not only the leaf dry weight yield that increased but the percentage content of sodium, and particularly chloride in those organs, as well (Tables $6,7,8$ ). This may indicate that Lolium perenne is a species resistant to salinity with sodium chloride, which was also confirmed by Yongqin et al. (2003).

High tolerance of a given species to salinity conditions in the soil is also confirmed by the results of proline content in the leaves. The mean level of the aminoacid in the grass leaves with salinity of $50 \mathrm{mM}$ increased nearly 4 times in relation to the control, and with salinity of $100 \mathrm{mM}$ as much as 13 times, which may indicate a strong stress effect of salinity conditions on plants. On the other hand, however, although accumulation of $\mathrm{Cl}^{-}$ions in the second crop increased in the leaves in relation to the first crop, the content of proline in those parts decreased as compared to the first crop by over $50 \%$ - and this, in turn, points to big adaptive capabilities of this species towards the stress of salinity (Table 9). Increased accumulation of proline in salinity conditions is also one of the signs of adjustment processes in plants, and similar changes were observed by Liang Huimin et al. (2001), and in other species of plants by Binzel et al. (1987), Roy et al. (1993), Mile et al. (2002) and Mansour et al. (2005). The obtained results also indicated that independently of the level of salinity and the date of the harvest, the lowest content of proline in the leaves was found in 'Ronija', significantly higher by 'Darius' and 'Stadion' and the highest by 'Nira'. The observed level of accumulation of the free aminoacid in the leaves of the studied cultivars of Lolium perenne corresponds well to the height of the leaf dry weight and the content of sodium and chloride in the leaves, which indicates that proline accumulation is a good indicator of the stress level in the plant. Bates et al. (1973) also think that the level of this aminoacid can be used as a biochemical indicator of a plant's tolerance to salinity or water deficit. 

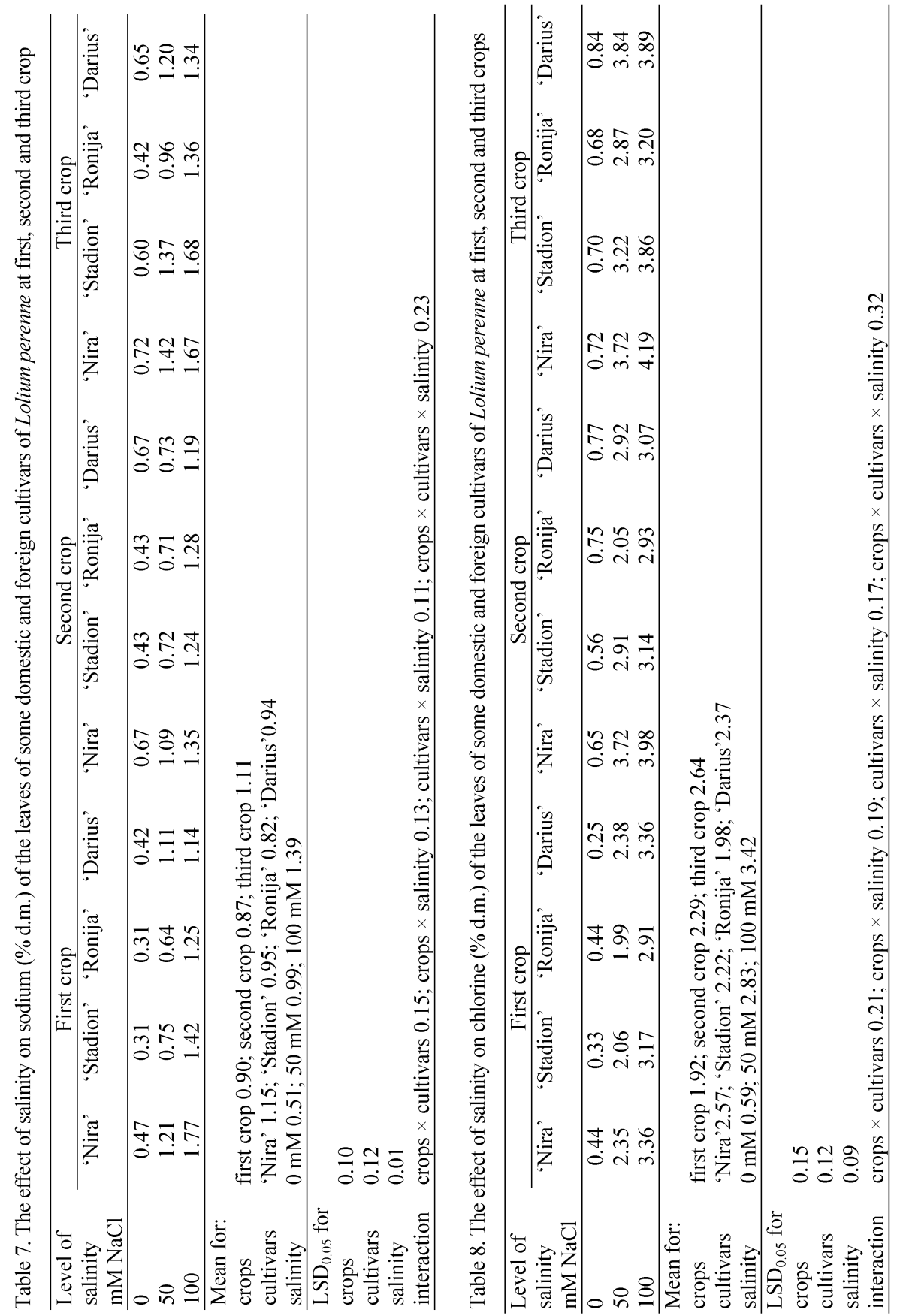


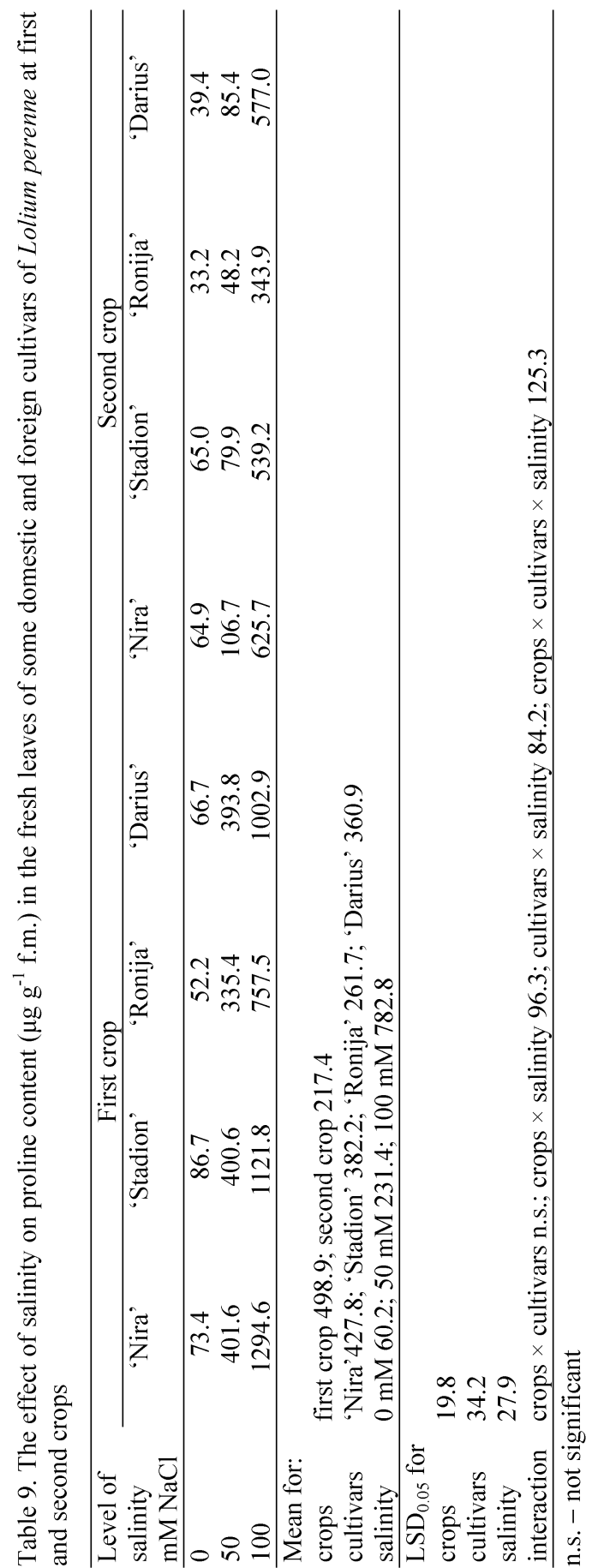




\section{CONCLUSIONS}

- The seeds of the studied lawn grasses tolerate salinity in the following sequence: Lolium perenne $>$ Festuca rubra $>$ Agrostis capillaris $>$ Poa pratensis.

- In the group of the studied Lolium perenne cultivars, 'Ronija' showed the greatest tolerance to $\mathrm{NaCl}$ salinity, 'Stadion' showed tolerance at a medium level, while 'Darius' - the least during the seeds germination and 'Nira' during the first year of growth.

- The degree of tolerance of the studied cultivars to $\mathrm{NaCl}$ salinity resulted from differentiated accumulation of sodium and chloride ions as well as free proline in the tissues. Tolerant cultivars contained less of the enumerated osmotically active compounds in the tissues.

- Changes in the content of $\mathrm{Na}^{+}$and $\mathrm{Cl}^{-}$ions and proline in the leaves during the plant growth in salinity conditions indicate that proline plays a special role in osmotic adjustment in the first weeks of growth, while later its role decreases, mainly for the benefit of chloride ions.

\section{REFERENCES}

ABDEl-KAdER D.Z., SAlEH A.H., 2002. Protection induced by external $\mathrm{Ca}^{2+}$ application on proline accumulation, ion balance, photosynthetic pigments, protein and ABA concentration of mustard seedlings (Sinapis alba L.) under salinity stress. Egyptian J. Biol. 4: 14-22.

Ashraf M., MCNeilly T., Bradshaw A.D., 1986. The potential for evolution of salt $(\mathrm{NaCl})$ tolerance in seven grass species. New Phytol. 103: 299-309.

Ashraf M., MCNeILly T., BRAdShaW A.D, 1990. Patterns of ion distribution in selected $\mathrm{NaCl}$ tolerant and normal lines of four grass species. Biol. Plant. 32: 302-312.

BAtes L., WALDREN R., TEARE J., 1973. Rapid determination of free proline for water stress studies. Plant Soil 39: 205-207.

BILSKI J., 1988. Reakcja roślin na stresy mineralne powodowane zakwaszeniem i zasoleniem środowiska. Część IV. Wpływ $\mathrm{NaCl}$ i $\mathrm{Na}_{2} \mathrm{SO}_{4}$ na wzrost i skład chemiczny siewek jęczmienia, pszenicy i owsa. Biul. Inst. Hodowli i Aklim. Roślin 165: 75-83.

BinZel M.L., HASEGAwA P.M., Rhodes D., HANDA S., HANDA A.K., BRESSAN R.A., 1987. Solute accumulation in tobacco cells adapted to $\mathrm{NaCl}$. Plant Physiol. 84: 1408-1415. 
BOROWSKI E., 2003. Sensitivity of domestic cultivars of soybean on salinity by sodium chloride. Part I. Effect of medium salinity on the growth of plants, gas exchange, nodulation of roots and content of sodium and chloride in plants. Ann. Univ. M. Curie-Skłodowska, sec. EEE 12: 93-102.

Brzóstowicz A., Musiat M., 1999. Effect of $\mathrm{NaCl}$ on plant growth and frost resistance of winter wheat 'Gama' cultivar. Zesz. Probl. Post. Nauk Roln. 469: 371-380.

CRAMER G.R., 2003. Differential effects of salinity on leaf elongation kinetics of three grass species. Plant Soil 253: 233-244.

GIBBEARD M.R., TURNER N.C., STOREY R., 2002. Influence of saline irrigation on growth, ion accumulation and partitioning, and leaf gas exchange of carrot (Daucus carota L.). Ann. Bot. 90: 715-724.

HANSLIN H.M., EGGEN T., 2005. Salinity tolerance during germination of seashore halophytes and salt-tolerant grass cultivars. Seed Sci. Res. 15(1): 43-50.

HORST G.L., DUNNING N.B., 1989. Germination and seedling growth of perennial ryegrass in soluble salts. J. Amer. Soc. Hort. Sci. 114(2): 338-342.

HUimin L., YANG X., Feng D., PUJIN Z., 2001. Effects of $\mathrm{NaCl}$ stress on physiological and biochemical indices of resistance of 2 turf grasses (Poa pratensis and Lolium perenne). Grassland of China 23, 5: 27-30.

HuJun L., Youzhen G., JiHe W., Mingui H., Zihui Y., 2001. A comparison on salt tolerance of 28 breeds of cold type lawn grass. Acta Pratacult. Sinica 10(3): 52-59.

Hussain M., NAEEM M., ASHRAF M.Y., IgBAL Z., 2002. Effects of $\mathrm{NaCl}$ salinity on growth and ion partitioning in some barley varieties. Online J. Biol. Sci. 2, 9: 608-611.

Hussain N., Ali A., KHAn A.G., Rehman O., TAhIR M., 2003. Selectivity of ions absorption as mechanism of salt tolerance in rice (var. Shaheen Basmati). Asian J. Plant Sci. 2, 5: 445-448.

Khan A.H., Ashraf M.Y., Nagvi S.S.M., KhanZada B., Ali M., 1995. Growth ion and solute contents of sorghum grown under $\mathrm{NaCl}$ and $\mathrm{Na}_{2} \mathrm{SO}_{4}$ salinity stress. Acta Physiol. Plant. 17, 3: 261-268.

Khan M.A., Ungar J.A., SHOWALTER A.M., 2000. Effects of salinity on growth water relations and ion accumulation of the subtropical perennial halophyte, Atriplex griffithii var. stocksii. Ann. Bot. 85: 225-232.

KHAN M.A., UnGan K.A., SHOWALTER A.M., 2000. The effect of salinity on the growth, water status, and ion content of leaf succulent perennial halophyte Suaeda fruticosa (L.). Forssk. J. Arid Environ. 45: 73-84. 
KIM K.S., YoO Y.K., LEE G.J., 1991. Comparative salt tolerance study in Korean lawn grasses. I. Comparison with western turfgrasses via in vitro salt tolerance test. J. Korean Soc. Hort. Sci. 32(1): 117-123.

MAGUIRE J.D., 1962. Speed of germination - aid in selection and evaluation for seedling emergence and vigor. Crop Sci. 2: 176-177.

Mansour M.M.F., Salama K.H.A., Ali F.Z.M., Haidid A.F., 2005. Cell and plant responses to $\mathrm{NaCl}$ in Zea mays L. Cultivars differing in salt tolerance. Gen. Appl. Plant Physiol. 31, 1-2: 29-41.

Mile O., MÉszÁros J., Veres S., LAKATOS G., 2002. Ecophysiological study on the salt tolerance of pannonion endemism (Lepidium crassifolium) in inland saline area. Acta Biol. Szegediensis 46, 3-4: 249-250.

MogSOOD A., VeRPLANCKE H., 1994. Germination and biomass production as affected by salinity in hydrogel treated sandy soil. Pakistan J. Forestry 44(2): 53-61.

MYERS B.A., COUPER D.J., 1989. Effects of temperature and salinity on the germination of Puccinellia capilla (Bor) cv. Menemen. Aust. J. Agric. Res. 40(3): 561-571.

PAWLUŚKIEWICZ B., 2000. Kiełkowanie i początkowy rozwój traw gazonowych w warunkach zasolenia i alkalizacji podłoża. Łąkarstwo w Polsce 3: 119-128.

Pervaiz Z., Afzal M., Xi S., Xiaoe Y., Ancheng L., 2002. Physiological parameters of salt tolerance in wheat. Asian J. Plant Sci. 1, 4: 478-481.

Roy D., BASAU N., BHUNia A., BANERJEe S.K., 1993. Counteraction of exogenous L-proline with $\mathrm{NaCl}$ in salt-sensitivar of rice. Biol. Plant. 35, 1: 69-72.

SEEMANN J.R., CRITCHLEY C., 1985. Effects of salt stress on the growth, ion contents, stomata behavior and photosynthetic capacity of salt-sensitive species, Phaseolus vulgaris L. Planta 164: 151-162.

STAWICKA J., WYSOCKI C., WIECZOREK J., 2006. The influence of soil salinity on floral variability of street lawns in Warsaw. Horticult. Landsc. Architect. 27: 73-81.

STIBOROVA M., KŠINSKA S., BŘEZINOWA A., 1987. Effect of $\mathrm{NaCl}$ on the growth and biochemical characteristics of photosynthesis of barley and maize. Photosynthetica 21: 320-328.

WYSOCKI C., 1994. Studia nad funkcjonowaniem trawników na obszarach zurbanizowanych (na przykładzie Warszawy). Rozprawy Naukowe i Monografie. Wyd. SGGW Warszawa: 1-89.

XiaOfang S., Haidong J., Zheng L., WeIXING C., 2000. Germinating characteristics of turfgrasses and forage grasses under $\mathrm{NaCl}$ stress. Grassland of China 6: 26-29. 
Yongqin D., Xuefang C., Weiping S., PING W., 2003. A screening of the salt tolerance variety of lawn grass by biotechnology. Acta Agr. Shanghai 19, 1: $37-40$

YUYING S., SuOMIN W., YAMING C., 1999. The effect of saline condition on the germination and its recovery of pasture species. Acta Pratacult. Sinica 8(3): 54-60.

\section{BADANIA NAD WRAŻLIWOŚCIĄ NIEKTÓRYCH GATUNKÓW I ODMIAN TRAW GAZONOWYCH NA ZASOLENIE CHLORKIEM SODU}

Streszczenie: W latach 2005 - $2006 \mathrm{w}$ badaniach prowadzonych w fitotronie $\mathrm{i}$ hali wegetacyjnej porównywano tolerancję na zasolenie $\mathrm{NaCl}$ nasion i roślin niektórych traw gazonowych. W warunkach fitotronu badano wpływ zasolenia chlorkiem sodu na kiełkowanie 4 gatunków traw, takich jak Lolium perenne odm. 'Info', Festuca rubra odm. 'Audio', Agrostis capillaris odm. 'Niwa', Poa pratensis odm. 'Alicja' i 4 odmian Lolium perenne - 'Nira', 'Stadion', 'Ronija', 'Darius'. Nasiona traw kiełkowały w płytkach Petriego, w ciemności przy temperaturze $24^{\circ} \mathrm{C}$. W badaniach obok kontroli zastosowano 3 poziomy zasolenia: 100,200 i $300 \mathrm{mM} \mathrm{NaCl}$. Uzyskane wyniki wykazały, że rosnący poziom zasolenia środowiska istotnie obniżał szybkość kiełkowania, liczbę wytworzonych korzeni, długość najdłuższego korzenia i długość koleoptyla siewek wszystkich badanych gatunków traw. Najlepiej tolerowały zasolenie nasiona Lolium perenne, a w następnej kolejności nasiona Festuca rubra, Agrostis capillaris i Poa pratensis. Natomiast tolerancja na zasolenie nasion badanych odmian Lolium perenne zmniejszała się według następującej kolejności 'Ronija' > 'Stadion', > 'Nira' > 'Darius'.

$\mathrm{W}$ doświadczeniach prowadzonych $\mathrm{w}$ hali wegetacyjnej określono tolerancję na zasolenie wymienionych 4 odmian Lolium perenne w pierwszym roku wzrostu. Rośliny rosły $\mathrm{w}$ wazonach o objętości $2 \mathrm{dm}^{3}$ wypełnionych mieszaniną ziemi uniwersalnej i piasku rzecznego (3:1 / v:v) przy wilgotności podłoża 70\% i 3 poziomach zasolenia: 0, 50 i $100 \mathrm{mM} \mathrm{NaCl}$. Uzyskane wyniki wykazały, że wzrost zasolenia powodował spadek plonu suchej masy liści w kolejnych zbiorach trawy, a wzrost w nich zawartości sodu, chloru i wolnej proliny. Największą tolerancję na zasolenie $\mathrm{NaCl} w$ grupie badanych odmian wykazała 'Ronija', średnią 'Darius' i 'Stadion' a niską 'Nira'. Wynikało to ze stopnia akumulacji jonów $\mathrm{Na}^{+}, \mathrm{Cl}^{-}$i proliny. Odmiany o wyższej tolerancji akumulowały mniej substancji osmotycznie czynnych w liściach. 